\title{
STRENGTHENING LOCAL INSTITUTIONS IN THE MANAGEMENT OF ADAT LAKES (BAKUOK LAKES) KAMPAR DISTRICT
}

\author{
Mimin Sundari Nasution, Zulkarnaini, and Mayarni \\ Jurusan Administrasi Publik, Fakultas Ilmu sosial dan politik, Universitas Riau. \\ E-mail: Mimin.sundari@lecturer.unri.ac.id; Zulkarnainfisip@lecturer.unri.ac.id; \\ Mayarni@lecturer.unri.ac.id
}

\begin{abstract}
A conservation area that has cultural-based fisheries activities, traditional leaders play a role as activity controllers and have a vision to conserve and provide protection in the area around this customary lake. On the other hand, ecologically, Bakuok Lake is very worrying. Based on the rules regarding the prohibition on Lake Bakuok, not all of these rules were carried out and implemented properly, even though there were already monitoring, there were still violations that occurred. The number of institutions involved in the development of Lake Bakuok have so far been temporary or temporary in nature, and have run separately and have not yet formed a systematic collaboration. This study aims to see how to strengthen local institutions in the sustainable management of Lake Bakuok. This research uses qualitative research methods that aim to obtain a holistic (holistic) picture of a phenomenon in Lake Bakuok. The results showed several important items that the institutional strengthening of lolak in the management of Danau Bakuok was not optimal. As seen from the dimension of human resource development that has not been maximized where there is no training or technical provisioning in order to increase skills. The dimension of organizational strengthening is also not optimal even though there is support for several activities but it is only temporary and unsustainable. Meanwhile, in the institutional reform dimension, it was found that several rules and regulations that had been made by ninik mamak were still violated.
\end{abstract}

Key words: Customary Figures; Institutions; Traditional Lakes; Sustainable Development.

\section{PENGUATAN KELEMBAGAAN LOKAL DALAM PENGELOLAAN DANAU ADAT (DANAU BAKUOK) KABUPATEN KAMPAR}

\begin{abstract}
ABSTRAK. Kawasan konservasi yang memiliki kegiatan perikanan berbasis kebudayaan, tokoh adat bereperan sebagai pengendali kegiatan dan memiliki visi untuk melestarikan serta memberikan perlindungan dikawasan sekitar danau adat ini. Di Sisi lain secara ekologis Danau Bakuok ini sangat memprihatinkan. Berdasarkan aturan tentang larangan di Danau Bakuok tersebut, tidak semua aturan tersebut terjalankan dan terlaksana dengan baik, meskipun sudah ada yang mengawasi, masih ada juga pelanggaran yang terjadi. Banyaknya kelembagaan yang terlibat dalam pengembangan Danau Bakuok selama ini masih bersifat temporal atau sementara, serta berjalan masing-masing dan belum membentuk kolaborasi yang sistematis. Penelitian ini bertujuan untuk melihat bagaimana penguatan kelembagaan lokal dalam pengelolaan berkelanjutan Danau Bakuok. Penelitian menggunakan metode penelitian kualitatif yang bertujuan untuk mendapatkan gambaran menyeluruh (holistik) dari sebuah fenomena di Danau Bakuok tersebut. Hasil penelitian menunjukkan beberapa item penting bahwa penguatan kelembagaan lolak dalam pengelolaan danau adat danau bakuok belum maksimal. Yang dilihat dari dimensi pengembangan SDM yang belum maksimal dimana tidak adanya training atau pelatihan dan pembekalan teknis dalam rangka peningkatan kemapuan. Dimensi penguatan organisasi yang juga belum maksimal walaupun ada dukungan untuk beberapa kegiatan namun hanya bersifat sementara dan tidak berkelanjutan. Sedangkan dimensi reformasi kelembagaan ditemukan bahwa beberapa aturan dan regulasi yang telah dibuat oleh ninik mamak masih banyak yang dilanggar.
\end{abstract}

Kata kunci: Tokoh Adat; Kelembagaan; Danau Adat; Pembangunan Berkelanjutan.

\section{INTRODUCTION}

No society or organization can exist without interaction with other communities or organizations that are mutually binding. The organization itself is part of the institution, so that the existence of the organization becomes an important technical part that ensures the operation of the institution. Institutions can develop well if there is an institutional infrastructure, there is an institutional arrangement, and an institutional mechanism. The combination of these various approaches can produce an adequate institutional analysis. The logic of institutional analysis can be used to explain the failure of policy makers to the development model. Collaboration between institutions also determines the success of a policy or program implementation (Damayanti, 2010).

Meanwhile, according to (Eaton, 1986), the strengthening of local government institutions is aimed at developing individual skills and competencies so that each individual is able to carry out the duties and responsibilities it carries, develop employees, culture, systems and processes into the authority / authority. organizational units in order to achieve the goals of their respective organizational units, and develop and strengthen development and strengthening of external links in order to develop an intensive, extensive and solid partnership 
(Abdurrahman, 2003).

In Riau Province, precisely in Kapubaten Kampar in Aur Sati Village, there is a lake called Lake Bakuok.

Lake Bakuok is a lake that has existed since the 14th century or thousands of years ago. This lake was formed due to the interruption of the Kampar Kanan river with an area of approximately 250,000 $\mathrm{m} 2$ with a length of $1 \mathrm{~km}$, a width of $250 \mathrm{~m}$ and an average depth of $2.98 \mathrm{~m}$. The source of this lake water comes from rain water. In addition, Bakuok lake is also a lake that is used as a place for fisheries conservation which is regulated in the Republic of Indonesia Government Regulation Number 60 of 2007 concerning Conservation of Fish Resources for protection, preservation and utilization of fish resources, including ecosystem, species and genetics to guarantee existence.

Lake Bakuok is a conservation area (Conservat area) and Lake Adat or lubuk prohibition which has cultural-based fishing activities, this can be seen with the activity of catching fish in the local language called "mauwo" which has become a popular party event. held once a year previously, fishing was allowed only once in 2 months. All activities carried out in Lake Bakuok are controlled by traditional Ministries who have the same vision in efforts to conserve and protect the lake area.

Ma'awuo Danau Bakuok is a tradition of catching fish together using nets, namely nets that use side scales. This Ma'awuo event is also one of the tourist destinations in Kampar Regency and has been included in the Riau Province annual calendar of events.

This activity has a good impact on the local community, namely improving the community's economy, by selling at Ma'awuo events and providing parking spaces. The fish catch can be enjoyed by the local community.

This Ma'awuo event could potentially damage the Bakuok lake conservation area, because the activities carried out were contrary to the purpose of making Bakuok Lake a conservation area and prohibited pond that should be able to protect the fish in the lake. It can be seen from the fishing gear used that it can capture the habitat in the lake.

In the upper reaches of the Kampar river there has been a change, which has an impact on the Lake Bakuok ecosystem, where fluctuations in water discharge are disrupted, causing the fish in the river to be unable to enter Lake Bakuok to spawn and vice versa. This lake is located in Aur Sati village, Tambang Subdistrict, Kampar Regency, the interesting thing about this lake is that this lake is designated as Lake Lubuk Larangan. Ecologically there has been a physical change from a flowing ecosystem in the form of a river to a flooded ecosystem (in the form of a lake). Physically, the river and lake have lost their ecological relationship, but the ecological relationship between the two can occur during the rainy season when the river overflows (flooding).

The position of the customary head and the village head is equal and work together to protect Lake Bakuok. In this case, the customary chiefs and ninik mamak have a role in making rules and restrictions regarding Bakuok lake, these rules aim to regulate the development and sustainability of the fishery ecosystem in Bakuok lake (Agusta, 2007).

Then the customary head and village head together with ninik mamak and their officials held a meeting and a group was formed to manage and supervise the lake called the Lubuk Ban group, which consisted of dubalang of 10 people from each tribe. And finally the community also plays a role in the management of this Bakuok lake by jointly maintaining the lake so that the lake is maintained and is protected from elements who catch fish carelessly.

In the development of Danau Bakuok, the institutions that play a role can be seen in table 1 . The existing institutions in managing Danau Bakuok consist of many stakeholders, who have their respective functions and contributions in managing Bakuok Lake.

Table 1. Institutional Contribution in the development of Lake Bakuok

\begin{tabular}{|c|c|c|}
\hline No. & Institutional & Contribution \\
\hline 1 & $\begin{array}{l}\text { Ministry of Fisheries } \\
\text { and Maritime Affairs } \\
\text { of the Republic of } \\
\text { Indonesia }\end{array}$ & $\begin{array}{l}\text { - } 1000 \text { fish seeds (catfish, gouramy, } \\
\text { lomak fish, motan fish (2015) } \\
\text { - 30,000 Nilem Fish Seeds (2018) } \\
\text { - 70,000 Lomak fish seeds (2018) }\end{array}$ \\
\hline 2 & $\begin{array}{l}\text { Riau Province } \\
\text { Fisheries Service }\end{array}$ & - 1000 Fish Seeds (2016) \\
\hline 3 & $\begin{array}{l}\text { Riau Province } \\
\text { Tourism Office }\end{array}$ & $\begin{array}{l}\text { 1. Construction of Traditional } \\
\text { Houses Around Lake Bakuok } \\
\text { 2. Promotion Through the Web } \\
\text { 3. Clothing assistance and mauwuo } \\
\text { event billboards } \\
\text { 4. Dancer assistance for the } \\
\text { opening of the Ma'awuo event } \\
\text { 5. Banner }\end{array}$ \\
\hline 4 & $\begin{array}{l}\text { District Fisheries } \\
\text { Office. Kampar }\end{array}$ & $\begin{array}{l}\text { 1. } 50 \text { tons of fish seeds }(2017) \\
\text { 2. } 5 \text { plaques }(2017) \\
\text { 3. } 1000 \text { Fish Seeds }(2018) \\
\text { 4. } 6 \text { canoes }(2015)\end{array}$ \\
\hline 5 & $\begin{array}{l}\text { District Tourism } \\
\text { Office. Kampar }\end{array}$ & $\begin{array}{l}\text { a) Promotion through the Web and } \\
\text { Social Media }\end{array}$ \\
\hline 6 & Riau LAM & \\
\hline 7 & Aur Sati village & $\begin{array}{l}\text { - Territory } \\
\text { - Planning and facilitating activities }\end{array}$ \\
\hline 8 & Ninik Mamak & $\begin{array}{l}\text { - Customary rules and laws } \\
\text { - Facilitation of Deliberation }\end{array}$ \\
\hline 9 & PTP NV & $\begin{array}{l}\text { 1. Assistance with borrowing lawn } \\
\text { mowers every month } \\
\text { 2. Lake water cleaning assistance } \\
\text { once a year }\end{array}$ \\
\hline 10 & PT. Hervania & \\
\hline
\end{tabular}

Source: Researcher Process, 2020 
In table 1 it can be seen that the institutional contribution to the development of Lake Bakuok, however, this institutional contribution is still temporary or temporary and institutionally not well documented. On the other hand, ecologically, Lake Bakuok is very alarming, with the existence of Palm and Rubber Trees planted on the edge of the lake, as well as the presence of fish cages. Based on the rules regarding the prohibition on Lake Bakuok, not all of these rules have been carried out and implemented properly, even though there are already people monitoring the lake there are still violations that occur. The number of institutions involved in the development of the Bakuok Lake has been running separately and has not yet formed a systematic collaboration.

Lake Bakuok is regulated based on customary law, in which the rules about the surroundings of Lake Bakuok are made directly by the customary head or local ninik mamak which is a form of policy from the customary chief and ninik mamak in the village. In the results of the Ninik Mamak Kenegerian TambangTerantang deliberation, a decision and regulation was made regarding the prohibition on Lake Bakuok. The rules are as follows:

1. Neither Ninik Mamak nor his nephews are allowed to plant oil palm on the other side of Lake Bakuok.

2. Ninik Mamak and his nephews are not allowed to make cages along the waters of Lake Bakuok, for those who have already made cages, they are only given permission for 1 harvest.

3. Ninik Mamak or her nephews are strictly prohibited from poisoning and electrocuting fish along the waters of Lake Bakuok.

The management of Bakuok lake with customary patterns, supported by many institutions involved in managing the Bakuok lake. Collaboration that runs will certainly be systematic, which will be collaborated, coupled with being used as a conservation area, allows for good collaboration with all stakeholders (Gumilar, 2012). The development of a managing organization that starts out simple can then develop.

Seeing the importance of Lake Bakuok for the community in terms of fisheries, economy, culture and other sectors and to conserve fish resources, institutional action is needed to support fish diversity and lake conservation areas. Based on the phenomena described above, the authors are interested in conducting scientific research entitled "Strengthening Local Institutions in the Management of Traditional Lakes (Bakuok Lake) Kampar Regency"

\section{METHOD}

This research uses qualitative methods, according to (Sidiq \& Achmad, 2020) Qualitative research for social studies is defined as an effort to understand social phenomena more broadly and more comprehensively, while according to (Moleong, 2009) The approach used in this study is a qualitative approach, an approach to understanding the phenomenon of what research subjects experience holistically. with descriptive in the form of words and language in a context, especially natural ones by utilizing various natural methods. Researchers consider that the qualitative method is the right method to be able to achieve the objectives of this study. The focus of this research was carried out in Bakuok Lake, Aur Sati Village, Tambang District, Kampar Regency, Riau Province.

The research method used interview technique purposive sampling with technical information from Tambang-Terantang and village officials who became informants in this study. The data used are primary and secondary data for analysis and research conclusions.

\section{RESULTS AND DISCUSSION}

Institutional Strengthening in Local Government Institutional Development according to Eaton (1986: 280), can be interpreted as an effort to properly build organizations, systems, partnerships, people and processes to carry out certain agendas or plans. Strengthening the institutional capacity of the Regional Government is therefore related to individual capability development, organizational capacity building, and institutional capacity building. The definition of institutional strengthening illustrates that there are many things that must be considered and examined carefully so that capacity building can produce tangible, beneficial, and positive results (Ife, 2008).

The presence of local institutions is not based on personal / individual interests but on mutual interests, so that local institutions over time occupy important positions in local government administration. The mutual trust of local community members that is raised and honed through this institution is increasingly being coveted as social capital. Local institutions turned out to be able to become the ethical frame of the local community (Purwosantoso, 2002; 10).

Basically, local institutions are the regulation of collective behavior, where social ethics rests, so that local institutions are able to produce the ability to regulate themselves from a normative perspective. Local institutions and social capital actually have a 
very big influence on local communities, therefore it is necessary to strengthen local institutions (Ginoga, 2005).

Capacity building has dimensions, focus and types of activities. The dimensions, focus and type of activity according to Grindle (1997:119) are:

1. Dimensions of human resource development, with a focus on: professional personnel and technical abilities as well as types of activities such as: training, hands-on practice, working climate conditions, and recruitment.

2. The dimensions of organizational strengthening, with a focus: management governance to improve the success of roles and functions, as well as types of activities such as: incentive systems, personnel equipment, leadership, organizational culture, communication, managerial structures, and

3. Institutional reform, with a focus on: institutions and systems as well as macro structures, with the type of activity: economic and political rules of the game, changes in policies and regulations, and constitutional reform

Based on the research results, it is known that the position of the customary head and village head is equal and works together. In this case, the customary head has a role in making rules and restrictions regarding Lake Bakuok, while the village head has a role to coordinate any matters related to the interests of Lake Bakuok. Then the customary head and village head together with ninik mamak and other village officials held a meeting and a group was formed to manage and supervise the lake called the Lubuk Ban Group, which consisted of dubalangs from 10 people from each tribe, to guard the lake for the lake. stay awake and avoid those who catch fish carelessly.

In terms of the dimensions of human resource development, the Kampar Regency Tourism and Culture Office, the Riau Province Tourism Office, and the Fisheries Service are institutions that play a role in providing and developing management capacity, but in this study it has not been found that related agencies provide training, direct practice or technical skills so that become a professional staff in the management of the Bakuok lake.

While the dimensions of organizational strengthening, it was found that the Riau Province Tourism Office participated in facilitating and providing support in the form of providing an arts (dance) team, providing banners and $\mathrm{t}$-shirts for the organizing committee, and promoting events at Bakuok Lake through social media. Meanwhile, the Fisheries Service has the role of providing fish seeds and fisheries-related needs (Hardjanto,2006).
Based on the rules regarding the prohibition on Lake Bakuok, not all of these rules have been implemented and implemented properly, even though there are already those who oversee the lake there are still violations that occur. patrolling and supervising dubalang or lubuk prohibition groups is also in charge of feeding fish. However, the existence of this group of lubuk prohibition does not fully function properly and can be said to be in name only.

The results of the research on Lake Bakuok still have other violations, namely the discovery of community cages in the lake and based on the results of an interview with a community that not all people want to obey the existing rules, because according to the fact in the field there are still a number of cages still available. In the lake, the community still maintains their cages because they feel they lose if they only harvest 1 time, their cage has to be opened, because their capital has not returned if they only harvest 1 time.

In addition, on the edge of the lake there are still many community-owned palm trees with an area of about $8 \mathrm{mx} 30 \mathrm{~m}$, which belonged to a community member planted on his private land. Even though they have been reprimanded and told to clean by ninik mamak, the community still does not pay attention to the warning and does not comply with the applicable rules.

Institutional strengthening in this study has dimensions, focus and type of activity. The dimensions, focus and types of activities in this study are:

a) dimensions of human resource development, with a focus on: professional personnel and technical abilities as well as types of activities such as: training, hands-on practice, working climate conditions, and recruitment.

b) dimensions of organizational strengthening, with a focus on: management governance to improve the success of roles and functions, and types of activities such as: incentive systems, personnel equipment, leadership, organizational culture, communication, managerial structures, and

c) institutional reform, with a focus on: institutions and systems as well as macro structures, with the type of activity: economic and political rules of the game, changes in policies and regulations, and constitutional reform

\section{Human Resources Development}

Setting a series of goals is an initial process which begins with decisions about the wants or needs of the organization and the work group. In managing this lake, it requires professional personnel who have 
technical capabilities and current conditions related to the Rawok Lake environment itself.

Formulating the current state is intended as an understanding of the current condition and the goals to be achieved or the resources available for achieving the goals. This is very important to do, because the goals and plans are related to the future. After knowing what are the goals of the Aur Sati and Ninik Mamak village governments in Aur Sati Village, a plan can be formulated to further describe the activity plan.The results of the study show that planning must be carried out in a big way so that the management of Lake Bangkuok will have an impact on the community. According to Eaton (1986) efforts to build organizations, systems, partnerships, people and processes correctly to carry out a certain agenda or plan. Strengthening the institutional capacity of the Regional Government is therefore related to the development of individual capacities, building organizational capacity, and building institutional capacity.

The management planning carried out by traditional leaders, such as making sheet piles around the area, ring roads. In the past, funds from the province had almost been realized but failed and only the existing hall on the edge of the lake has been running and implemented and the ring road that has been successfully operated and opened (alikodra,2012).

Based on the results of the research above, we can see that a plan has been made while paying attention to and considering the current situation and conditions that will occur in the future by the government and Ninik Mamak but it has not been realized properly due to constraints on funding and differences of opinion. between ninik mamak and the village. In implementing the plans that have been made, guidance, direction or training from related institutions is necessary. In terms of the dimensions of human resource development, the Department of Tourism and Culture of Kampar Regency, the Tourism Office of Riau Province, and the Department of Fisheries are institutions that play a role in providing and developing the capacity of managers, but in this study, the relevant agencies have not found any training, direct practice or ability. technical personnel in order to become professionals in the management of the Bakuok lake.

Meanwhile, to build quality human resources and increase the organizational needs ofDanau Benok, according to (Kurniasih, 2017) Human resources will produce a strengthening model for institutions, this model is defined as an administrative network, a pattern of responsibility that is implemented for institutional strengthening.

\section{Organizational Strengthening}

Organizing is the basic activity of management carried out for and managing all required resources including the human element, so that work can be completed successfully. The purpose of the organization is to guide people to work together effectively.

Organizing occurs because the work that needs to be done is too heavy to be handled by one person. Thus, assistance is needed and an effective work group is formed. Many thoughts, hands and skills are gathered into one that must be coordinated not only to complete tasks. the task concerned, but also to create uses for each member of the group against his desires skills and knowledge (Manalu, 2017).

Good organizing is an integrity of the things that affect the success of an organization or company to achieve its goals. As for organizing in Lake Bakuok Governance in Aur Sati Village, Tambang District, Kampar Regency, it can be seen from the following indicators:

\section{a. Division of Duties}

The division of tasks is an absolute thing to do in the organization so that there is no overlap in the implementation of work, so that it does not create vacancies at one point or field and avoids the accumulation of work at other points or areas. . The division of tasks should be adjusted to the ability of individuals in the group, in fact the division of tasks leads to the formation of a section in the management of Lake Bakuok based on local wisdom in Dea Aur Sati, Tambang District, Kampar Regency.

The results of the study illustrate that the organizations that have been formed are POKDARWIS and Lubuk larangan groups, these groups contain traditional leaders and ninik mamak, this group has a division of tasks such as national tourism events events, according to Beckhard (1969) organizational development is a process. the behavior of division of tasks in organizations whose purpose is to provide intervention, planning, improvement and strengthening of strategies for more advanced institutions.

From the research above, we can conclude that each group or organization already has its respective duties and is formed from the local village community and from the ninik mamak itself, even though the group has been formed, their existence and function are not completely running well, the existence of the group and even then, sometimes only at the event. Based on the observations that the researchers saw in the field, that the duties and functions of the dubalang had not been going well because there were still violations that had occurred in Bakuok Lake.

The opinion above is in line (Kurniasih, 2017) with the results of research which states that collaborative has an important role in building 
community involvement. This model is able to strengthen network systems and information flows and reduce disagreements between stakeholders. This model can also clarify the roles of each stakeholder and their accountability

\section{b. Authority}

To complete an organization, employee units are combined together through an authority that determines the relationship between these units. Someone is needed to direct the activities of each unit towards organizational goals. A superior / leader has the right or authority to carry out and give orders to his subordinates to carry out its authority.

Authority is the basis for acting, acting and carrying out activities / activities. As for the dual function of authority, namely the responsibility which is the responsibility of each individual to carry out activities to the best of his ability. Without authority in the organization, it will be difficult to carry out management activities. that has been planned.

The results of the study explain that the parties who manage and have the authority over Lake Bakuok are the ninik mamak and nephews. The role of the village is only to provide permits for place and territory. Village power is only in the area and power over activities lies with the ninik mamak. If the village does not agree with the activities that will be made, the ninik mamak will continue to carry out these activities. Because like it or not, adat is older than this village, so between the government, the ulama, the ninik mamak are still in line, they cannot overlap.

From the results of this study, it can be concluded that the one who has full authority over the management of Lake Bakuok is ninik mamak, so all decisions are in the hands of ninik mamak, because this area still uses customary law, so everything goes according to existing customary laws. Meanwhile, the Riau Province Tourism Office participated in facilitating and providing support in the form of providing an arts (dance) team, providing banners and T-shirts for the committee, as well as promoting events at Bakuok Lake through social media. Meanwhile, the Fisheries Service has the role of providing fish seeds and fisheries-related needs.

The above research is in line with the opinion (Nono, 2011) authority will have an impact on institutions, if the authority in each organization is managed professionally, the goals will be achieved especially in the economic field, human resources will increase accordingly.

\section{Institutional Reform}

Institutional reform, with a focus on institutions and systems and macro structures, with the type of activity: economic and political rules of the game, changes in policies and regulations, and constitutional reform. As for the series of work activities that will be carried out based on the results of the needs of the community, Village-Owned Enterprises (BUMDES) will later manage activities that generate money and village regulations will be made as a basis (Nasrul,2017).

From the results of the above research we can conclude that in developing a plan or a series of work activities, a legal basis must be made first so that the activities made can be carried out optimally and in accordance with existing regulations (Haryono, 2011).

All management is given to the surrounding community and represented by traditional leaders, local government, so in implementing lake management, the functions and roles of relevant agencies are only as facilitators of existing activities, such as providing assistance and promoting activities in Lake Bakuok through social media and others.

Based on the rules regarding the prohibition on Lake Bakuok, not all of these rules are carried out and implemented properly, even though there are already overseeing the lake there are still violations that occur. patrolling and supervising dubalang or lubuk prohibition groups is also in charge of feeding the fish. However, the existence of this group of lubuk prohibition does not fully function properly and can be said to be in name only.

When researchers conducted research on Lake Bakuok, there were still other violations, namely the discovery of community cages in the lake and based on the results of an interview with a community that not all people wanted to obey the existing rules, because according to the fact in the field there were still a number of cages. who are still in the lake, the community still maintains their cages because they feel they lose if only 1 harvest, their cage has to be opened, because their capital has not returned if only 1 harvest (Buwono, 2017).

In addition, on the edge of the lake there are still many community-owned palm trees with an area of about $8 \mathrm{~m} \times 30 \mathrm{~m}$, which belonged to a community member planted on his private land. Even though they have been reprimanded and told to clean by ninik mamak, the community still ignores the warning and does not comply with the applicable rules.

\section{CONCLUSION}

The strengthening of local institutions in the management of customary lakes or Danau Bakuok in Kampar district has not been implemented optimally. Ninik Mamak has a significant role in managing Lake Bakuok in Aur Sati Village, all decisions or regulations are made based on the agreement of 
Ninik Mamak in Tambang District. Institutional strengthening should be able to minimize violations that occur in the management of the lake. On the other hand, the management of the lake in Aur Sati Village, Tambang Subdistrict, Kampar Regency, must continue to work in synergy with related agencies, preferably providing training, guidance or direction in maintaining the ecology of Bakuok Traditional Lake. The training provided should be continuous, not just temporary ceremonial assistance.

It is hoped that Ninik mamak or the village government will make stronger rules and sanctions so that there will be no more violations committed by the community. The government is expected to increase the budget for the management of Lake Bakuok in Aur Sati Village, Tambang District, Kampar Regency, so that the implementation of Lake Bakuok management can run well and achieve the expected goals.

\section{REFERENCES}

Abdurrahman, (2003). Pembangunan Berkelanjutan Dalam Pengelolaan Sumber Daya Alam Indonesia. Seminar Pembangunan Hukum Nasional VIII. Denpasar

Agusta, I. (2007). Penguatan Kelembagaan Untuk Pengembangan Kawasan Agropolitan. Pelatihan Nasional Dan Implementasi Pengembangan Kawasan Agropolitan. Bogor: P4W-LPPM-IPB Dan Yayasan Tunas Mandiri Nasional.

Alikodra, H.S. (2012). Konservasi Sumber daya alam dan Lingkungan. Yogyakarta: Gajah Mada University Press

Buwono, Y.R. (2017). Identifikasi dan Kerapatan Ekosistem Danau Bakuok Di Kawasan Teluk Pangpang Kabupaten Banyuwangi. Samakia: Jurnal Ilmu Perikanan, 8, (1), 32-37. https:// doi.org/10.5281/jsapi.v8i1.271

Damayanti, A. (2010). Kebijakan Pembangunan Wilayah Berbasis Pengelolaan Das Terpadu Dan Berkelanjutan. Bogor: Institut Pertanian Bogor

Eaton, J.W. (1986). Pembangunan Lembaga Dan Pembangunan Sosial. Jakarta: Universias Indonesia

Ginoga, K., Luginam M. \& Djaenudin, D. (2005). Kajian Kebijakan Pengelolaan Hutan Lindung. (Policy Analysis of Protection Forest Management). Jurnal Penelitian Sosial \& Ekonomi, 2, (2), 203-231.
Grindle, M.S., (editor). (1997). Getting Good Government: Capacity Building in the Public Sector of Developing Countries, MA: Harvard Institute for International Development. Boston.

Gumilar. I. (2012). Partisipasi Masyarakat Pesisir dalam Pengelolaan Ekosistem Hutan Danau Bakuok Berkelanjutan di Kabupaten Indramayu, Jurnal Akuatika, III, (2), 198-211.

Haryono, B.S. (2011). Pembangunan Kapasitas Pemerintahan Daerah Dalam Menyelenggarakan Urusan Kesehatan di Kota Malang. Malang: Fakultas Ilmu Administrasi Universitas Brawijaya.

Hardjanto, I. (2006). Pembangunan Kapasitas Lokal (Local Capacity Building). Malang: Program Pascasarjana Universitas Brawijaya.

Ife,J.\&Tesoriero,F.(2008). Community Development, Alternatif Pengembangan MAsyarakat di Era Globalisasi, Yogyakarta: Pustaka Pelajar

Kurniasih, D. (2017). Model Penguatan Kelembagaan Pada Program Sanitasi Lingkungan Berbasis Masyarakat (Slbm) Di Kabupaten Banyumas (Suatu Pendekatan Collaborative Governance). Sosiohumaniora, 19, (1), 1-7. https://doi. org/10.24198/sosiohumaniora.v19i1.7888

Manalu, R. \& Rhama, B. (2017). Penguatan Kelembagaan Lokal di Kawasan Taman Nasional Sebangau. JISPAR, Jurnal Ilmu Sosial, Politik dan Pemerintahan. 6, 2, 1-11.

Moleong, L. J. (2014). Metodologi Penelitian Kualitatif. Bandung: PT. Remaja Rosdakarya.

Nasrul, W. (2017). Peran Kelembagaan Lokal Untuk Penguatan Pasar Pertanian Gambir (Uncaria Gambir Roxb). Jurnal Sosiologi Pedesaan. 5, (1), 47-51

Nono, O.H. (2011). Dampak Kelembagaan Bagi Hasil Terhadap Kinerja Usaha Penggemukan Sapi Potong Di Kabupaten Kupang. Sosiohumaniora, 13, (1), 28-38.

Purwosantoso. (2002). Institusi lokal dalam perspektif Good Governance. Yogyakarta: IRE

Sidiq, R.S.S. \& Achmad, R.W.W. (2020). Gender aspects in remote indigenous community empowerment program in Indonesia. Journal of Advanced Research in Dynamical and Control Systems, 12, (6), 2104-2109. https:// doi.org/10.5373/JARDCS/V12I6/S20201172 